\title{
"I Would Kill the Director and Teachers in the School" Cyberbullying of Hunters in Poland
}

\author{
Aleksandra Matulewska ${ }^{1}$ (D) - Dariusz J. Gwiazdowicz ${ }^{2}$ (D)
}

Published online: 29 May 2020

(c) The Author(s) 2020

\begin{abstract}
The aim of the paper is to focus on cyberbullying (Donegan in Elon J Undergrad Res Commun 3(1):33-42, 2012) affecting the community of hunters in Poland. The investigation reveals that linguistic aggression pervades more and more spheres of our lives and the Internet, which gives anonymity and physical distance, is the main forum of cyberbullying. The researchers investigate the material gathered from websites such as "Ludzie przeciw myśliwym" [Humans against hunters], hunting-related blogs and Facebook sites devoted to hunting and related to persons who are known to be hunters (e.g. spokesmen of the Polish Hunting Association). The problem of the stereotypical perception of hunting is also raised (Bartmiński and Chlebda in Etnolingwistyka 25:69-95, 2003. https://doi.org/10.17951/et.2013.25.69). The issues of prejudice, stereotyping and lack of knowledge result in the possibility of inciting people to cyberbully others. People brought up in cities, far away from nature, are easily convinced to attack other groups which they perceive as deviant (Bartmiński and Chlebda 2003). The verbal aggression deeply rooted in stereotypes and prejudice based on limited knowledge of nature, overly idealistic and naïve worldviews becomes more and more widespread. Therefore, the authors intend to provide some insight into the problem of cyberbullying of hunters in Poland in order to find the patterns of that activity from socio-semiotic perspective analyzing verbal signs and symbols used to justify that sort of behaviour as well as socio-linguistic perspective concerning the usage of emotion-loaded language. Additionally psycholinguistic issues will be touched upon as well as the problem of shaping the image of hunters by media will be discussed.
\end{abstract}

Keywords Cyberbullying · Verbal aggression · Law $\cdot$ Cyberbullying of hunters

Aleksandra Matulewska

aleksmat@amu.edu.pl

http://www.scopus.com/inward/authorDetails.url?author

$\mathrm{ID}=36080591800 \&$ partnerID $=$ MN8TOARS

Extended author information available on the last page of the article 


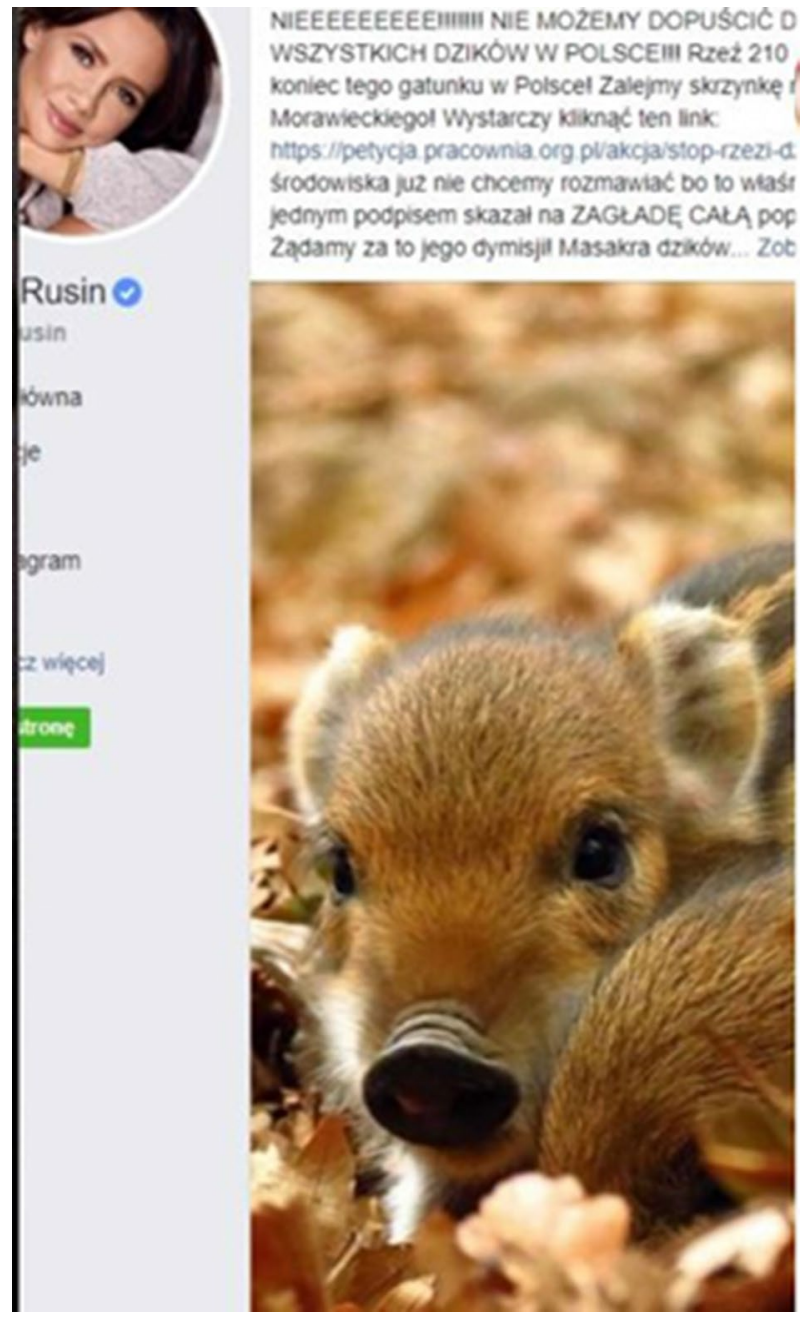

Fig. 1 The opinion on the reduction of wild boars in Poland

\section{Introduction}

The Internet and social media are an important source of information and creating attitudes especially among younger age groups [1]. The freedom and unrestricted publicity of comments mean that we use this medium very often and without inhibitions. The profiled accounts of famous people (celebrities) and the information they contain are observed by huge numbers of followers. Among the many topics that are the subject of public debates, discussions and disputes that cause great emotions are sustainable wild game management and, above all, hunting.

An example in this regard may be the activity of a Polish journalist who frequently posts comments on her social media profile (Figs. 1 and 2) on hunting. On 


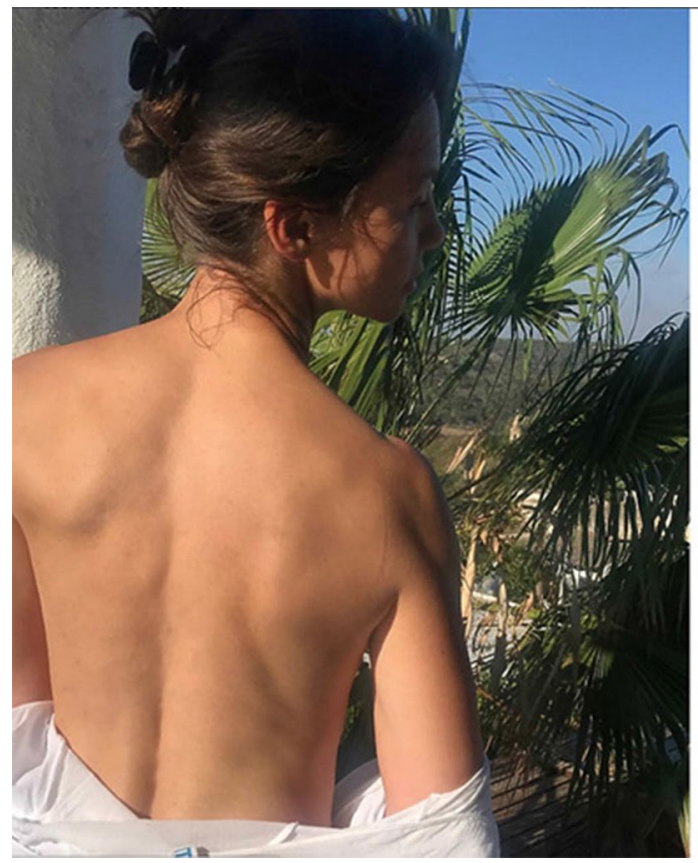

kingarusin • Obserwowanie

kingarusin Czy gdybym się rozebrała, byłaby szansa, żeby portale i gazety napisały o tym, że w Polsce w czasie rykowiska myśliwi zabijają otumanione hormonami jelenie? Czy wtedy podaliby link do petycji, która może je uratować: http://petycja.pracownia.org.p//petycja/ryk owisko-dla-jeleni-nie-dla-mysliwych Bo bez golizny ani skandalu, żeby przebić się z naprawdę ważnymi sprawami nie ma szans.

Pod petycją potrzeba minimum 50 tysięcy podpisów, żeby mogła być skuteczna. Jeszcze nam trochę brakuje. Wiem, że w Polsce są miliony osób, które kochają przyrodę i zwierzęta tylko nie wiedzą, że właśnie teraz potrzebujemy ich glosu. Powiedzmy im co się dzieje i razem zmieńmy tẹ straszną sytuację. Razem możemy więcej.

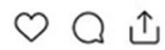

Liczba polubień: 13304

4 GODZ. TEMU

Dodaj komentarz..

Fig. 2 Propagating a petition concerning red deer protection during their mating season

numerous occasions she posts comments showing her limited knowledge in the field. That was the case of the campaign aimed at banning hunting for black grouse despite the fact that the bird is protected in Poland and any instance of killing it is an act of poaching.

In another post the journalist wrote "NOOOOOO!!!!!!! WE CANNOT ALLOW ALL WILD BOARS IN POLAND TO BE KILLED!!! The slaughter of 210,000 (!!!) wild boars means the end of this species! Let's flood the mailbox of Prime Minister Morawiecki with our veto!" And posted a cute photo of little wild boars (Fig. 1).

Of course, the truth is different, because the extinction of the species has never been planned. What was planned was only the reduction of the species population due to the spread of ASF (African swine fever) in compliance with the UE recommendations. The message was strengthened by a photo of small animals, which always arouse strong emotions. This is a well-known and often used social engineering method called "Baby-Schema" (schemat dziecięcości in Polish, Kindschen-Schema in German), which effectively affects not only children but also adults. "Baby-scheme" is a term used in social psychology proposed for the first time by K. Lorenz, the Nobel Prize winner in 1943. It specifies the factors triggering instinctive need in adults, even the compulsion to look after others. It is often used in the production of toys and in advertising. One of the tricks is showing small animals and children, which is to release the caring and protection instincts [cf. 2-6]. Sometimes the image of young mammals is used not only in 
advertisements and commercials, but also in psychological manipulations, e.g. as in the example above. What is surprising, the species of mammals and birds are much more appealing for money donors than for instance amphibians which are much more endangered with extinction. The act of killing a frog does not arouse as strong emotions as the act of killing a dog or a deer.

Another example is given in Fig. 2, where the same journalist is struggling to stop hunting red deer by writing, "if I had undressed, would there be a chance that portals and newspapers would write about the fact that hunters in Poland kill red deer disoriented with hormones during their mating season? Would they then provide a link to a petition that could save them [...]".

In reality, however, the number of red deer in Poland is growing dynamically and continuously, and the extent of damage caused by them is increasing. National Forests which manage forests covering the area of over 7 million ha spend about PLN 180 million (over EURO 42 million) per year on deer fencing. Despite such actions, as a result of foraging the surface of about 90 thousand hectares is damaged [7]. In the picture presented above, the erotic photograph is to catch the attention of the recipient, which is also a sociotechnical measure.

Another example of manipulation is information provided by the Forest Patrol-People Against Hunters that a hunter was hunting deer using snares (Fig. 3, left). In fact, the photograph comes from the Center of the Periodic Animal Rehabilitation in Jelonki and depicts a roe deer tangled in a wire fence in a field (Fig. 3, right). The text reads: "We were called by the police to help a male roe deer whose head, neck and antlers were tangled in a wire fence. The animal breathed heavily. The more scared deer jerked, the more the wire tightened. We managed to untangle the animal with difficulty, and after releasing the roe deer run away from us as fast as it could. Dear farmers check from time to time your wire fences as something similar may happen at your location". The inscription at the print screen on the left reads: "AT HIS FIELD THE HUNTER PLACED SNARES INTO WHICH ROE DEER GOT CAUGHT. One of the members of the Polish Hunting Association, who has a plot of land in Kmiecin village (Pomerania region) has placed in melioration ditches such traps [literally: structures] made of wire with blue isolation secured on metal poles. The effect... wild animals going to water reservoirs and crossing the field got caught...". As can be seen from the pictures, both pieces of news present the same animal. What is more, the news on the righty was published first.

Such emotional approach as the above-mentioned one to managing living natural resources, the stereotypical approach to the tasks performed by hunters and the manipulation of public opinion through sociotechnical measures and even lies bring expected results. Internet users are outraged by the activities of hunters. They express their anger and outrage in their comments. The discussion becomes more and more emotional and consequently leads to brutalization of the language and speech. Of course, you can also find in the social discussions substantive statements about the hunting management, arguments for and against hunting (reduction of certain species, hunting season timelines), but they were not the subject of this article. Well-substantiated criticism cannot be treated as an act of cyberbullying no matter whether we share the point of view of the criticizing person or not. Though, in order 


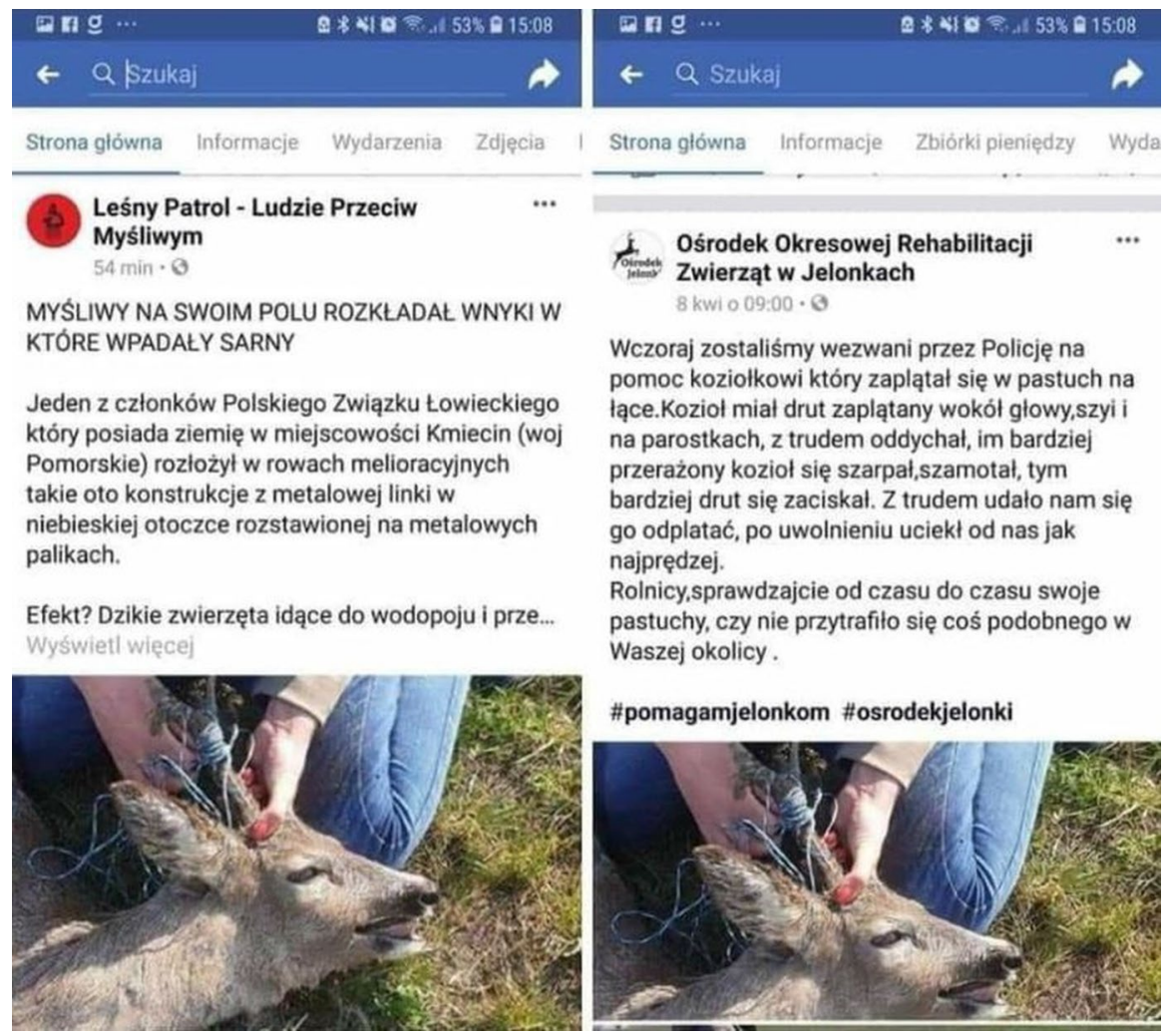

Fig. 3 The example of manipulation and fake news in social media

to be treated as criticism such opinions must be expressed in accordance with social norms of communication-they must be pragmatically correct.

The aim of the paper is to focus on cyberbullying [8] affecting the community of hunters in Poland. The phenomena of cyberbullying and hate speech have been reaching unprecedented scales due to the rapid development of IT and the Internet. The easy access to huge numbers of people has opened a completely new possibilities of exploring the psychology of crowds [9].

\section{Research Methods and Material}

The research methods encompass:

1. the socio-semiotic analysis of (i) the role of hunting in Poland based on scientific literature; (ii) comments on Facebook websites and other Internet resources devoted to hunting and hunting criticism; 
2. the linguistic analysis of (i) vulgarisms and offensive language, (ii) intensity of hate-based rhetoric and finally (iii) explicitness and implicitness of language used in Internet-published comments;

The research material is composed of (i) pertinent literature and legislation on cyberbullying, hate speech, hunting, biodiversity and related problems as well as (ii) Facebook websites and other Internet resources devoted to hunting and hunting criticism. Some of the materials were provided to the authors by persons who were attacked on the Internet for being hunters.

\section{Cyberbullying}

The aim of the paper is to focus primarily on cyberbullying which as some scholars claim "may be one of the "diseases" of the 21th century. Despite efforts to curtail its incidence and prevalence over the past 20 years, its direct and indirect harmful effects have made it a public concern about the wellbeing of children, adolescents, and adults." [10]. Cyberbullying is a relatively new phenomenon which has occurred with the emergence of the ubiquitous Internet and social media pervading all spheres of our lives in contemporary Information Age. It "refers to any harassment that occurs via the internet, cell phones or other devices. Communication technology is used to intentionally harm others through hostile behaviour such as sending text messages and posting ugly comments on the Internet" [11]. Furthermore, cyberbullying is a phenomenon difficult to identify and assess until severe consequences occur such as suicides or instances of physical violence ending in bodily harm or even death. One cannot also ignore psychological effects of that type of bullying, though they will not be scrutinized here as they are considered the domain of psychology and psychiatry rather than linguistics.

According to the National Crime Prevention Council "Cyberbullying is similar to other types of bullying, except it takes place online and through text messages sent to cell phones" [12] and it is aimed at embarrassing, humiliating or intimidating a bullied person. The identification of cyberbullying may be difficult due to the fact that sometimes it takes the form of spreading rumours or gossips but there is a thin line between a typical social phenomenon which is gossiping and posting malicious texts which incite hatred, defame or humiliate other human beings. Therefore, we may also find definitions which stress that it is the process of "willful and repeated harm inflicted through the medium of electronic text" [13].

The problem of Internet aggression is observed all over the world where people use that medium of communication. Scholars analyse it from various perspectives and that is why they also stress that:

"The definitions of internet aggression vary across studies. Typically, it is defined as 'overt, intentional acts of aggression toward others online' [14]. Cyberbullying is another name for internet aggression, which includes specific behaviors such as rude, embarrassing, threatening, or harassing comments, unwanted sexual comments, and exclusion [15, 16]." [17] 


\section{Hate Speech Typology}

In general, hate speech refers to verbal utterances which are formulated to attack a person or a group of persons who are featured by some characteristic not approved of by a certain person or group. Among such features we may enumerate the most typical ones such as race, sexual orientation, ethnic origin, nationality and religion. However, there are also less frequently encountered features such as disability, gender and gender identity, profession, occupation or undertaken activities.

There are numerous typologies of hate speech but for the purpose of this paper the typology based on four dimensions of hate speech will be used [18]. The hate speech may be identified taking into account four dimensions that is to say:

1. the type of targeted group which is treated as a group of some sort of deviants due to stereotyping [cf. also 19-22];

2. the usage of vulgarisms and offensive language aimed at offending, humiliating, threatening a given person or group [23-26];

3. intensity of the hate-based rhetoric; and finally

4. explicitness or implicitness of rhetoric.

As already mentioned in this paper the focus will be put on the group undertaking specific activities that is to say hunters in Poland.

The analysis of the usage of vulgarisms and offensive language under scrutiny will limit the research mostly to utterances in which the offensive or abusive language serves the purpose of offending, humiliating, threatening, etc.

Before classifying some utterance as a hate-based rhetoric, a text must be analyzed taking into account the emotional load of the utterance as it may be

1. a critical text expressing ones attitude or emotions which despite being loaded with negative emotions cannot be classified as hate speech as it is a critic, nothateful merit-based attitude which is allowed under the principle of the freedom of speech;

2. a text which is loaded with the incitement to hatred or which even may be interpreted as a call to violence against a person or some group or even lynch; and finally

3. a text constituting an assault on human dignity and aiming at degrading, humiliating and dehumanizing a person or group.

Finally, a hate-based rhetoric may be assessed taking into account the criterion of its explicitness and implicitness or in other words evaluating "whether the rhetoric is direct and explicit, or it is veiled and reliant on external information to accomplish its objective." [18] When taking that aspect into account one may also pose questions whether the rhetoric is based on facts and merits of criticism or merely on stereotypical views of very superficial nature. 
Gagliardone et al. [27] in a publication released by the United Nations Educational, Scientific and Cultural Organization (UNESCO) distinguishes two types of hate speech:

1. "Expressions that advocate incitement to harm (particularly, discrimination, hostility or violence) based upon the targets being identified with a certain social or demographic group" [27].

2. "Expressions that foster a climate of prejudice and intolerance on the assumption that this may fuel targeted discrimination, hostility and violent acts" [27].

Those typologies will be used to analyse the collected research material from the socio-semiotic perspective.

\section{A Case Study of Hate Speech and Cyberbullying Against Hunters}

\subsection{The Targeted Group and Activity-Knowledge Versus Stereotyping}

The history of hunting has tens of thousands of years on the European continent. Initially, hunting was the basis of human existence and stimulated civilization development. The hunt, or rather the success achieved during the hunt, provided meat, furs for clothing and bones for making everyday tools. However, after the Neolithic revolution, when men acquired the ability to cultivate land and breed certain species of animals, hunting changed its role. It became a form of entertainment for court elites, higher classes of society. Of course, venison, antlers or furs were still valued, but their supply was handled by the lower social classes [28].

Nowadays, hunting has ceased to be the basic source of food supply, it is also not a form of entertainment or fun, although this is often perceived that way. A few decades ago, a new stage in the history of hunting began and today we are living in a transitional period. We participate in changes that are taking place at the moment. In order to better understand the tasks facing modern hunting, it is necessary to consider social expectations. We all want to live safely, comfortably and prosperously, which is why we change the natural environment constantly. We develop housing, create new jobs, construct highways, and the structure of agricultural crops is continuously changing. This landscape changes taking place in front of our eyes are the result of human transformations. This results in a diversification of environmental conditions-for some animals living conditions are now better, and therefore their numbers are increasing significantly, but for others extremely negative, and therefore there are fewer and fewer of them. The basic task of modern hunters is to support endangered species, but also to reduce those that pose a threat to our life and health or cause excessive damage, thus hindering forestry, agriculture or fishing and fishery industries [29].

To achieve the above objectives, specific legal regulations have been enacted in Poland based on the Hunting Law (Journal of Laws of 1995, No. 147, item 713, as amended) [30]. Below some articles from this legislation are presented. 
Art. 1. Sustainable hunting, as an element of natural environment protection, within the meaning of the Act means the protection of game animals (wild game) and management of their resources in accordance with the principles of ecology and the principles of rational farming, forestry, fishing and fishery. (Art. 1. Łowiectwo, jako element ochrony środowiska przyrodniczego, w rozumieniu ustawy oznacza ochronę zwierząt łownych (zwierzyny) i gospodarowanie ich zasobami w zgodzie z zasadami ekologii oraz zasadami racjonalnej gospodarki rolnej, leśnej i rybackiej) [30].

Art. 3. The purpose of hunting shall be: (1) the protection, preservation of diversity and management of populations of wild game; (2) the protection and shaping of the natural environment for the improvement of habitats of animals; (3) obtaining the highest possible condition of animals and quality of trophies as well as the appropriate number of populations of particular game species while maintaining the balance of the natural environment; (4) meeting social needs in the field of hunting, cultivating tradition and propagating ethics and hunting culture. (Art. 3. Celem łowiectwa jest: (1) ochrona, zachowanie różnorodności i gospodarowanie populacjami zwierząt łownych; (2) ochrona i kształtowanie środowiska przyrodniczego na rzecz poprawy warunków bytowania zwierzyny; (3) uzyskiwanie możliwie wysokiej kondycji osobniczej i jakości trofeów oraz właściwej liczebności populacji poszczególnych gatunków zwierzyny przy zachowaniu równowagi środowiska przyrodniczego; (4) spełnianie potrzeb społecznych w zakresie uprawiania myślistwa, kultywowania tradycji oraz krzewienia etyki i kultury łowieckiej.) [30].

Art. 4.1. Sustainable hunting management shall be an activity in the field of protection, breeding and acquisition of wild game (Art. 4.1. Gospodarka łowiecka jest to działalność w zakresie ochrony, hodowli i pozyskania zwierzyny) [30].

Art. 32. The Polish Hunting Association shall be an association of natural and legal persons who actively participate in the protection and development of wild game and act to protect nature. (Art. 32. Polski Związek Łowiecki jest zrzeszeniem osób fizycznych i prawnych, które czynnie uczestniczą w ochronie i rozwoju populacji zwierząt łownych oraz działają na rzecz ochrony przyrody).

From the above cited provisions it is clearly seen that the purpose of hunting is not to meet the personal and individual needs of hunters (e.g. sport, recreation, entertainment). The goal is primarily to protect and rationally manage the population of wild animals (which is distinguished by bold print). Hunters, however, face an extremely difficult and challenging task, because on the one hand they are notoriously criticized by foresters and farmers that they reduce too few animals and, as a consequence, damage to forests or fields is too great. On the other hand, they are criticized by animal defenders that they reduce at all. Activists of some social organizations have launched aggressive campaigns in Poland aimed at banning hunting 
entirely. One of their forms of activity are entries in social media aimed at discrediting hunters. They often take the form of verbal aggression and sluggish language. They also include petitions to liquidate natural history museums or to limit the admittance to such museums by introducing the age limit-only for persons who have attained the age of majority (which in Poland is 18). They claim that exhibiting corpses of animals is unethical, causes shock to children and teenagers and may result in psychological disorders and pathologies. Such actions are very effectively broadcast on social media (in Poland mainly Facebook). The consequences are very serious as teachers are afraid to take school kids to such museums and the drop in the sale of tickets follows. In the case of culture institutions it is a serious problem (information directly obtained from the director of one of the natural history museums in Poland).

The problem of the stereotypical perception of hunting is also important [31] because the concepts of species preservation (biodiversity preservation) via sustainable hunting and hunting management is not popular in Poland despite EU legal regulations in this respect e.g. the Birds' Directive [32], The European Charter on Hunting and Biodiversity [33], Natura 2000 Networking Program [34], Recommendation No. 128 (2007) of the Standing Committee on the European Charter on Hunting and Biodiversity [35], etc.

\subsection{Vulgarisms, Offensive Language and Intensity of Hate-Based Rhetoric}

Before we start investigating vulgarisms and offensive language used in the analysed material, it seems necessary to provide the definition, typology and functionality criteria of such linguistic units.

Focusing on the definition of vulgarisms there is no denying the fact that they are lexical units which infringe linguistic norms, they are taboos and at the same time they enable the speakers to express their emotions in a straightforward manner [36: 19]. On the other hand Markowski [37: 97] focuses on vulgarisms which are considered by him as they describe in a vulgar way the physiological activities covered by moral taboos and serve the purpose of expressing the negative emotions of the speaker towards the surrounding world. Płóciennik and Podlawska [38: 296] state that those are linguistic units which are very expressive, blunt and coarse words used to express excessively negative attitude for instance to people. At the same time it should be stressed that the profile of vulgarisms' users has changed significantly within the last two or three decades. The so-called educated people were expected in the past to use the language reflecting their social status, that is to say they were not expected to use vulgarisms in public domains. As a result, vulgarisms were associated with lower classes of society, criminals and other types of pathological groups. It finds reflection in some definitions of that lexical phenomenon. According to one of them a vulgarisms is "an expression, phraseological unit or statement generally recognized as violating the principles of decency, good manners, blameworthy from the point of view of the principles of morality. Vulgarisms occur in the colloquial language, especially in slang versions, used by people occupying the lowest positions in society (e.g. criminals, prisoners)" [39: 312]. Nowadays, however, we 
observe the increased number of people using vulgarisms also in public domains regardless of their social status, social background, acquired education, et cetera. It may be due to the impact of mass media on societies and the increased number of vulgarisms present in movies and pop culture. In the past television and radio served the purpose of spreading and disseminating culture, knowledge, and principles desirable from the perspective of the state and society as a whole. But the expansive flood of Hollywood made movies filled with gradually increasing numbers of vulgarisms accompanying violence presented on the screen resulted in vulgarisms being no longer considered taboo in many social spheres of life. For many people they became lexical units customarily used to express negative emotions to certain elements of life. Kowalikowa [40: 107-108] observes that shift in vulgarism usage stating that vulgarisms are used by people "of different ages, representing different social groups, occupations, educational level, gender." Therefore vulgarisms may be considered as offensive means of expressing emphasis for negative emotions and they may be divided into (i) systemic vulgarisms and (ii) referential and moral profanities. Systemic vulgarisms infringe linguistic conventions no matter the context of their usage. Such vulgarisms may be divided into three categories, that is to say, mildly vulgar words, vulgar words, and extremely vulgar words. Referential and moral profanities in turn may infringe linguistic conventions but only in certain pragmatic situations [36: 20-21]. Vulgarisms and profanities should not be mixed with swear words as they have a completely different function because they are aimed at expressing emotions of the speaker without conveying any offensive or aggressive message against somebody. They simply serve as an outlet of emotions. That category of swear words will not be taken into account in the analysis provided below as such linguistic units cannot be treated as the hate speech manifestations and consequently do not serve the purpose of cyberbullying due to the limited linguistic function.

We must inevitably take into account invectives which are "spontaneous expressions, revealing the emotions of the speaker towards the addressee" [36: 22]. The aim of the invective is to inform the addressee of the message about the negative emotions felt towards him by the speaker. In general their primary aim is to make the addressee of the message feel ashamed, humiliated, offended, degraded etc.

\subsubsection{Reasons for Vulgarism Usage}

The pertinent literature on vulgarisms also provides us with some insight into the reasons for vulgarism usage. One of the reasons has already been stated above that is to say the possibility to release negative emotions by linguistic means. However, it is only one of many reasons for vulgarism usage. The list of potential reasons for vulgarism usage is the following:

1. releasing negative emotions including aggression;

2. provoking the message addressee to take part in the dispute or argument;

3. shocking the participants to the communication process;

4. expressing objections; 
5. offending the addressee which may take place when the speaker feels powerless against the problem or the interlocutor because he or she has no arguments which are based on merits and which may serve fruitful discussion;

6. filling the message with semantically empty words [37, 41].

The reasons for vulgarism usage may also be sociological, psychological, rhetoric, communicative, linguistic and fashion related [42: 128].

The sociological reasons serve the purpose of integrating and identifying oneself with a given group. In such instances vulgarisms have phatic function facilitating communication with members of a specific group. The sociological function is also exploited when vulgarisms are used to express objections, rebellion and opposition.

The psychological reasons are more complex. Vulgarisms are used to express feelings which cannot be accurately described by the available linguistic resources. From the psychological point of view vulgarisms also serve the purpose of showing dominance and superior position towards the interlocutor. In some pragmatic situations they may be used to relieve the tension by achieving for instance a humorous result. The psychological function is also exploited when vulgarisms are used to please others and impress them with courage, bravery, adulthood.

Next, the rhetoric function may be exploited in circles of good friends. In such instances vulgarisms serve the purpose of expressing empathy, diminishing the communication distance. But at the same time it may be a tool of making a mockery of someone as well.

When speakers want to neutralise emotions, offend someone, put extra emphasis to their attitude to a problem or issue in dispute the communicative function of vulgarisms is realized.

The linguistic function is strictly connected with the economy of language usage as the expressive force of vulgarisms enables to achieve the maximum communication effect by using the minimum number of words and speech formulation effort. It has been observed that people with limited command of their native language exploit that function of vulgarisms using them as semantically empty verbal fillers or semantic means of precision. The analysis of real life comments frequently led to the conclusion that vulgarisms had the linguistic function.

As it has been already indicated above the usage of vulgarisms is also connected with fashion and the impact of mass communication and popular culture on the linguistic behaviours of language users who adopt the models promoted by mass media and convert them into linguistic habits. Sometimes such fashion based habits are called cultural stimulators.

\subsubsection{Functions of Vulgarisms}

According to Kowalikowa [42: 129-130] the following functions of vulgarisms may be distinguished:

(a) the persuasive-imperative function-which is aimed at strengthening the line of argumentation very frequently in situations when the speaker lacks arguments 
which are merit based, feels powerless and unconvincing when disputing with the interlocutor,

(b) the therapeutic-relaxation function-which is aimed at achieving emotional discharge of usually negative emotions,

(c) the compensating function-which is aimed at concealing the lack of self-assurance, uncertainty,

(d) the identifying function-which is aimed at creating a bond with a group,

(e) the disciplining and indoctrination function-which is primarily aimed at criticizing someone's actions, stigmatising,

(f) the intensifying function-which is aimed at putting some emphasis on something,

(g) the degrading and offensive function-which is aimed at offending, insulting, degrading and humiliating the interlocutor,

(h) the phatic function up-which is aimed at maintaining contact between interlocutors

(i) the ludic function-which is aimed at achieving the interlocutor's amusement and bringing humour to the conversation.

Another typology of Kowalikowa [40: 109-111] divides the functions of vulgarisms into: (i) primary and (ii) secondary ones. In general, in the context of cyberbullying the secondary functions are of no importance as they consist in the phatic and ludic functions described above. At the same time primary functions should be explored in more detail, as they encompass the expressive and impressive functions. The expressive function is aimed at expressing emotions both positive and negative (releasing the tension, stress, aggression). Vulgarisms at the expressive level may be used to reveal positive feelings such as admiration, nice surprise but also negative ones including hatred, aggression, violence. The impressive function serves the purpose of offending or humiliating someone.

\subsection{Explicit and Implicit Cyberbullying-Threats and Contempt}

The next part of the paper presents the examples of real life comments illustrating the verbal aggression and offensive language directed at hunters in Poland.

Some of the comments refer to the change in the role of hunters and reveal the stereotyping perception of sustainable hunting limited only to the thoughtless killing of animals. The comments show that the persons communicating their opinions have almost no environment related knowledge.

\section{Example 1}

"Hunters, really?! Hunters were once, a long time ago, when they had to get food, furs. The animals had a chance, and they [hunters] respected their pray. Today they are sadistic, perverted murderers! (Jacy myśliwi?! Myśliwi to byli kiedyś, bardzo dawno temu, gdy musieli zdobywać jedzenie, skóry. Zwierzęta miały 
jakieś szanse, a oni szanowali swoje ofiary. Dzisiaj to są sadystyczni, zboczeni mordercy!)

\section{Example 2}

“This is fucking sick. I will not express myself otherwise. Fucked. I don't believe in any overpopulation of boars or other animals. There are too many Chinese, too. Nature would cope with it alone. Under no circumstances it is normal to kill animals lured to some kind of murder shop. This isn't even hunting anymore. This is a fucking massacre.” (To jest kurwa chore. Inaczej się nie wyrażę. Popierdolone. Nie wierzę w żadne przeludnienie dzików, czy innych zwierząt. Chinczykow też jest za dużo. Natura sama by sobie poradziła. W żadnym wypadku nie jest to normalne, zabijac zwierzęta zwabione do jakieś mordowni. To już nawet nie jest polowanie. To jest kurwa masakra.]

In Example 1 the expression "sadistic, perverted murderers" is not a vulgarism but rather referential and moral profanities. Whereas in Example 2 vulgarisms are used. They have mostly the expressive function. They aim at releasing emotions and put an extra emphasis to the message, making it an outburst of outrage. Thus, they have the intensifying function as well.

The second group of comments which we may distinguish are simply vulgarisms and offensive language directed at hunters. They aim at degrading, depreciating and humiliating hunters (cf. Example 3 below). They may be classified as invectives.

\section{Example 3}

"Fucking motherfucker. I would take beautiful photos of him with a rifle in his ass." (Pierdolony skurwysyn. Bym mu zrobił piękne zdjęcia z karabinem w dupie.)

\section{Example 4}

"Hunter = walking shit." (Myśliwy = chodzące gówno.)

\section{Example 5}

"Motherfuckers!!! not people.” (Skurwysyny!!! nie ludzie.)

Vulgarisms used in Examples 3-5 have the impressive function and aim at degrading and humiliating hunters. The same purpose have comparisons containing vulgarisms or offensive language that is to say "walking shit" and "motherfuckers-not people". Their function is to offend the addressee without giving arguments that are based on merits and may be classified as the persuasive-imperative function as well. Additionally, the offensive language used in Example 3 aims at achieving the ludic function, that is to say incite amusement. 
Some of the comments in fact focus on the psychological condition one must suffer from if he or she is a hunter. The most frequent psychiatric disorder present in the comments is psychopathy (cf. Example 6).

\section{Example 6}

"Psychopaths, for treatment in closed wards." (Psychopaci, do leczenia w ośrodkach zamkniętych.)

\section{Example 7}

"And Bloody Diana qualifies only for the treatment of psychiatric disorders!" (A Krwawa Diana nadaje się tylko do leczenia zaburzeń psychiatrycznych!)

There are also references to social disorders such as deviations which are understood in sociological categories as practicing behaviours which are learnt in the process of socialization in a given social community but are typical of some minority and therefore are not acceptable in dominant communities (communities which form the majority of society) [cf. 43]. Most of such theories claim that criminal behaviours are non-hereditary but they are acquired in the course of bringing up and socialization [44]. In accordance with such theories, the urge to kill animals is also the result of upbringing and exposing a child to brutality and violence. It is acquired through communication and other types of social interactions. All such behaviours considered deviant require learning techniques for committing acts and specific motivation, aspirations, rationalization and attitudes. Hunters are considered criminals. That way hunters are perceived as a sort of subculture, the community of deviants. As deviants they are perceived as persons committing acts having no moral justification. What is more, they are perceived as insensitive persons, having no conscience and sense of guilt [43]. The community of hunters is associated with criminal or conflict subcultures. Such terms which are used in the language of medicine as technical, scientific terms denoting medical conditions and diseases (a psychopath suffers from psychopathy or sociopathy, a sadist is a person suffering from a sadistic personality disorder, an alcoholic suffers from an alcohol abuse) become extremely offensive in colloquial speech but are not strictly vulgarisms. The names of intellectual development disorders which denote illnesses perceived as especially shameful undergo a constant process of euphemizing. With the flow of time they stop being acceptable and become offensive. That was the case of terms such as imbecile, idiot, moron which were replaced with mentally retarded which in course of time has been replaced with presently acceptable intellectually disable. In general and colloquial languages they are referential and moral profanities.

What follows below are comments combining features discussed in reference to psychological and social disorders when focusing on Examples 6 and 7. 


\section{Example 8}

"I have already written it: outlaw!!! These are psychopaths and deviants!!!!!!" (Ja już to pisałam: zdelegalizować!!! To są psychopaci i dewianci!!!!!!)

They are also considered criminals despite the fact that the activities of hunters are regulated by law and sanctioned by law.

\section{Example 9}

"I have a gun permit. Can I shoot at hunters? Why not if they can shoot at those poor animals? Ohhh Mogę strzelać w myśliwych? Skoro oni mogą w biedne zwierzaki. Ehhh

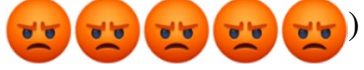

In Example 8 the exclamation marks are enhancing the force of the message. After the first sentence urging to ban hunting three exclamation marks follow, whereas after the second one diagnosing the conditions in psychiatric and social categories six exclamation marks follow. In Example 9 the commentator enhances the message by using five emojis. The rhetorical question suggests that hunters are the same category of criminals as those who kill other people.

Finally, they are accused of sadism and torturing animals for pleasure.

\section{Example 10}

"Hunters are sadists and psychos how can you allow a slow painful death of an animal whose life was taken away, you must have no feelings and heart" (mysliwi to sadysci I psychole jak mozna pozwolic na powolna bolesna smierc zwierzecia ktoremu I tak zabralo sie zycie, trzeba nie miec uczuc I serca).

\section{Example 11}

"whores not people. they are not hunters but sadists drunk panhandlers who run and murder in the woods" (kurwy nie ludzie. to nie myśliwi tylko sadysci dziady zapijaczone po lesie biegaja i mordują)

There are also instances when comments urge to stigmatize hunters (Example 12) or even urge to kill them (Example 17). Some of them may be considered calls for lynch.

\section{Example 12}

"Down with hunters!!!! Let's stigmatize killers of our animals every time and on every occasion" (Precz z myśliwymi!!!! Piętnować morderców NASZYCH zwierząt na każdym kroku i przy każdej okazji). 
Examples 9, 10, 11 contain referential and moral profanities aiming at offending and humiliating the hunters. At the same time they enable the outlet of anger. Example 12 is also a call for action: stigmatizing hunters.

There are also comments having the features of ill-wishing, enchanting, bad luck bringing (Examples 13-16).

\section{Example 13}

"Wives beat them at home, they take their anger out on defenseless animals!! Regular motherfuckers!!! sons of bitches!!!! 1 wish they rot!!!" (Baby w domu ich biją to na bezbronnych zwierzętach się wyzywaja!! Zwykłe ścierwa!!! skurwysyny!!!! żeby tak zgniły ścierwa!!!)

\section{Example 14}

"Karma will come back to you, you mentally fucked murdereress!!!!!! You'll regret for all the animals, you slut and you will rot in the fucking prison!!!!!!! Then you will feel yourself how you will get fucked in your slut face every day;) let some dog bite you to death you fucking whore:)". (Karma wróci do ciebie, psychiczna zjebana morderczyni!!!!!! Pozalujesz za te wszystkie zwierzęta szmato i będziesz gnić w pierdlu!!!!!!! Wtedy sama odczujesz jak będziesz dzień w dzien dostawac w pierdol w ta swoja zawistna morda (;) oby cie jakiś piesek zagryzł na śmierć PIERDOLONA kurwo:))

In Examples 13-14 vulgarisms have the impressive function and are aimed at offending and humiliating hunters. Those two messages have therefore the degrading and offensive functions.

\section{Example 15}

"I would kill the Director and Teachers in the School" (Zabiłabym Dyrektora i nauczycieli w szkole)

Example 15 differs as it contains a direct threat. The quote which is also used in the title "I would kill the Director and teachers in the School" was taken from the comments that were posted after publishing on the Internet a newspaper report concerning the extracurricular class organized by one of female hunters in a primary school. The class was organized for children and their parents were free to choose whether they would attend it or not. It was devoted to the recognition of species of animals frequently mistaken in Poland (red deer, roe deer, fallow deer) and the discussion concerning the role of hunting in biodiversity preservation. A few local newspapers published short reports concerning the aim of the class. The reaction of newspaper readers was astonishing as it turned out to evoke incredible verbal aggression. It is formulated as a conditional clause with one part missing but that part is easy to decode: "If it happened in the kindergarten to which my 
child goes". There is no hesitation in the statement. At the same time, the killing of the mayor of the city of Gdańsk (Poland) which took place on $13^{\text {th }}$ January 2019 during a major Polish charity event, proves that cyberbullying and cyberaggression find their tragic outcome in real life. At nearly the same time, Polish press informs about a sentence given against a man who committed a crime of money extortion under the slogan "donate the money to solve the problem of hunting" and who incited for aggression against hunters (successfully gathering money under false pretense).

\section{Example 16}

"They should be punished for every animal killed because they are God's creatures, they go to church and pretend to be Catholics, confess and think that crimes have been turned off and they are wrong here. Before you aim read the Bible and you will see you bastard that you will not be forgiven and hell will be waiting in that world but who knows, maybe evil will return as well." (Powinni być karani za każde zabite zwierzę bo to są stworzenia Boże chodzą do kościoła i udają katolików spowiadają się i myślą że zbrodnie zostały wyłączone i tu się mylą zanim wycelujesz przeczytaj Biblię a przekonasz się dziadu że nie zostanie ci wybaczone i piekło będzie czekało na tamtym świecie ale kto wie może i na tym zło powróci).

Example 16 is of a different nature to some extent. It is an instance of patronizing and revealing hypocrisy by juxtaposing Catholic values with behaviour of hunters. Therefore, it has the disciplining and indoctrination functions.

Many out of these examples relate to the criticism of hunting understood as animal reduction, which the authors think is unnecessary.

Additionally, based on the analysis of the Polish language and a multitude of errors (the authors preserve the errors in their English translations as much as possible), it can be presumed that on numerous occasions people with a low level of education wrote them.

Sometimes the attacks targeted specific people, well-known hunters. The spokesman of the Polish Hunting Association, who was wrongly accused of abuse of the dog, could have felt this badly. Although the information was false, a wave of Internet hate flooded her. Internet users wrote for instance:

\section{Example 17}

"Kill the bitch and the rest of hunters who torment dogs in such a manner!!

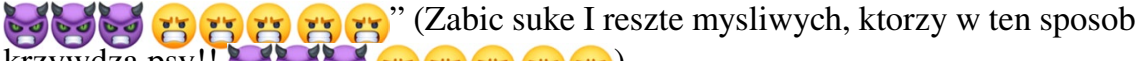

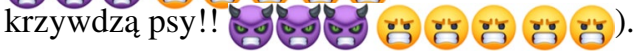

In Example 17 the term "bitch" is used having again an expressive function. The profile of a commenting female had an inscription with emojis of flowers and hearts stating "Replace your anger with love and your suffering will end" which stands 
in contradiction to the outburst of anger and aggression expressed in the comment. This example is also a call for lynch.

Another phenomenon could be seen after the press release published on December 30, 2017, when the nationwide daily Gazeta Wyborcza, known for its aversion to hunters, reported a drama on a hunt during which one hunter shot his colleague dead. Below the journalistic information there were comments from the Internet version readers:

\section{Example 18}

“A dead hunter is a good hunter" (Martwy myśliwy to dobry myśliwy)

\section{Example 19}

“Good news :) Let them shoot each other dead!” (Dobra wiadomość :) Niech się wzajemnie wystrzelają !)

\section{Example 20}

"He went to kill and killed, so congratulations are due" (Poszedł zabijać i zabił, więc należą się gratulacje)

\section{Example 21}

"Good hunting. One psycho less" (Dobre polowanie. Jednego psychola mniej)

\section{Example 22}

"It serves them right! May all those torturers shoot themselves dead" (Dobrze im tak! Oby wszyscy ci oprawcy sami się powystrzelali)

\section{Example 23}

"These thugs in feather hats will shoot each other dead being drunk at nights — it's great" (Te bandziory w kapelusikach z piórkiem wystrzelają się na wzajem w nocy po pijaku — jest super)

\section{Example 24}

"What fuucking kind of drama? One of few good pieces of news this year... One psychopath-sadist less..." (Jaki koorwa dramat??? Jedna z niewielu dobrych wiadomości w tym roku... Jednego psychopaty-sadysty mniej...) 


\section{Example 25}

"The best hunt is when one hunter shoots another dead :)" (Najlepsze polowanie jest wtedy, kiedy jeden myśliwy ustrzeli drugiego :))

\section{Example 26}

"One pathology less - bravo - keep it going” (O jedną patologię mniej - brawo - tak trzymać)

\section{Example 27}

"I'm very happy, I can't wait when all those legalized killers get fu... [ck] ed dead by... each other, but please let it happen quickly! (Bardzo się cieszę, doczekać się nie mogę kiedy ci wszyscy zalegalizowani zabójcy powypie...ja się wzajemnie, byle szybko!)

\section{Example 28}

"I wish you a nice convulsions dying in cancer torments... it should happen to EVERY corpse/dead-meat eater..." (Życzę miłego zdychania w męczarniach na raka... to się należy KAŻDEMU trupożercy...)

The examples quoted above in general express an extremely negative attitude to hunters. They combine ill-wishing (Examples 18, 19, 22, 23, 25, 27, 28) and the impressive function $(21,27$,$) . The authors resort to various linguistic resources to$ achieve their communication aim starting with comparisons (Examples 18, 31), imperative mood (Example 19), rethorical questions (24, 32, 33), exclamations (Examples 19, 22, 27), irony (Examples 20, 30), stereotyping (Example 23), short messages-message banners (Examples 21, 25, 26).

There were just few comments regarding the tragedy that actually happened-the death of a man. One of the people wrote:

\section{Example 29}

"A man died in a tragic accident. Condolences to the family and his loved ones. I am ashamed of some comments." (W wyniku tragicznego wypadku zginą człowiek. Wyrazy współczucia dla Rodziny i Jego najbliższych. Wstydzę się z powodu niektórych komentarzy).

This opinion evoked disapproval and received the largest number of "dislikes", and Internet users commented on it as follows: 


\section{Example 30}

The family deserve compassion. He went hunting and did not bring meat. They will have to drink during his funeral eating pickled cucumbers (Rodzina zasługuje na współczucie. Poszedł na polowanie, a mięska nie przyniósł. Będą musieli pić na tej stypie pod ogórka)

\section{Example 31}

"Not a man but a hunter. The hunter murders defenseless animals and that way no longer deserves to be called a human being" (Nie człowiek, tylko myśliwy. Myśliwy mordowaniem bezbronnych zwierząt wypisuje się z grona ludzi godnych tego miana).

\section{Example 32}

"He went to kill and died, isnt’t it justice?" (Poszedł zabijać i zginął czy to niesprawiedliwe?)

\section{Example 33}

"Why this unreasonable compassion? Did you bet money on the loser?" (Skąd to nieuzasadnione współczucie? Postawiłeś pieniądze na przegranego?)

After $6 \mathrm{~h}$, new information appeared on the newspaper's website and the topic about the hunters was no longer visible. The number of entries dropped dramatically and after $24 \mathrm{~h}$ it almost froze. Nearly 450 entries appeared under the information about the hunting accident and only few expressed regret and considered the event a tragedy as a human being died.

On June 26, 2018, in the Bieszczady Mountains, in the town of Strzebowiska, a wolf attacked two children (an 8-year-old girl and a 10-year-old boy) who played outside. The same wolf had previously attacked a woman in a neighbouring village called Wetlina. Because of the danger the animal posed to human beings, it was shot by hunters at the request of the community with the officially issued permit. After a press release in a daily Gazeta Wyborcza presenting this event, Internet users posted their comments. Nobody expressed concern for children, no one asked about their health. All comments were focused on the "poor wolf" who was "killed by cruel, degenerated hunters".

Such a narrative is not surprising, since the campaign "Let them live" has been conducted in Poland for many years. It aims to humanize animals and fight against hunters. On the website of activists from this movement, you can read: "All species of birds have their own complex families and emotional lives. They also bring up children, work hard, experience mourning after losing a partner, love, cheat, fight for their homes, get food for their family. There is monogamy among most birds. A goose killed in the hunt, orphaning the family, leaves a lonely partner who may not form a bond with anyone else for the rest of their life" [45]. 
We seem to be witnessing something important. What we increasingly observe in social media is the anthropomorphization of nature, personification of trees, humanization of animals and animization of men. An example analyzed by Borowicz [46] (forthcoming) was the death of a horse in 2014, on a frequented tourist route in the Tatra Mountains. About 200 people gathered at the place of the horse's death. At the same time a person died a sudden death about $150 \mathrm{~m}$ from the place of the collapse of the horse. There only three people gathered and watched the corpse. The death of the horse became media information. The death of the woman did not catch attention of the public.

\section{Concluding Remarks}

The offensive language which is used by persons verbally attacking hunters on the Internet and the arguments used by authors of such entries clearly indicate that the knowledge about sustainable hunting management practice in Poland and the role of hunting is none or extremely limited. The fact that the messages are mostly filled with the emotions such as hatred, aggression, contempt and the merits are not taken into account make such messages instances of cyberbullying. Additionally, the argument for treating them as such is the fact that we may find threats against hunters and descriptions of tortures that that they should be subjected to.

The language used indicates that hunters are considered deviants. They are called psychos, sadists, psychopaths, mentally ill, etc. As sustainable wild life management is mostly not known to common people, we may draw a conclusion that limited knowledge on environment, rights of nature and the impact of human activities on environment is extremely limited. Offensive signs and vulgarisms mostly serve the purpose of offending and humiliating (impressive function). We may also encounter threats. The intensity of hate-based rhetoric varies, but in general the messages containing vulgarisms are the examples of explicit hatebased rhetoric, whereas the ones which resort to irony mostly feature implicit hate-based rhetoric. The intensity of hate based rhetoric is stressed by claiming that hunters are not human beings, they do not deserve to be called human beings, using animalization of hunters (e.g. calling someone's face a snout, etc.). In fact, the majority of examples can be classified as expressions advocating incitement to harm and foster a climate of prejudice and intolerance. Stigmatization is one of the techniques of expressing explicit intolerance and hostility towards hunters.

The problem of verbal aggression which is not stigmatized and considered unacceptable is more complex. Some authors investigate how to stop it and what sort of deterrents may be effective [17, 47]. There is no denying the fact that verbal aggression acceptance may lead to the escalation of anger. That may have disastrous consequences in the form of acts of physical violence, aggression and other undesirable actions. They may include violent protests, leading to scaring decision-makers who may be prompted to make decisions which are not best in a given situation. In Poland the actions include destroying the property, setting 
deathly traps (a bomb planted on a hunting stand) $[48,49]$ and using fake news to defame some people or groups.

It seems that the increasing aggression on the Internet directed at hunters is due to the tacit consent to such activity. It is supported by activists and some celebrities with a passive attitude of hunters. As a consequence, the phenomenon is escalating, there are protests and actions blocking hunting. In recent years, the first symptoms of ecoterrorism directed against hunters have been noted. It has included undercutting the hunting stands in such a way that they would overturn when hunters would be on top of them, digging in beams with nails to pierce the tires and cause the hunter's car to collide. However, the climax of this escalation occurred at the end of last year. As reported in a local daily titled Gazeta Pomorska of December 28, 2019 [49], a mortar shell with attached wires was installed on one of the hunting stands. Tossing explosives at hunting facilities is a proof of the direction in which the form of aggression being analyzed can develop. Its purpose is to intimidate hunters and make them abandon their statutory obligations.

The phenomena described above should stimulate the entire community to unequivocally oppose the aggression on the Internet and encourage to take effective actions aimed at its elimination. Today, it is directed towards hunters, but there is a greater activity of activists fighting foresters, farmers, fishermen, etc. [50]. This, in turn, stimulates aggression on the Internet also against these professional groups. Additionally, it should be borne in mind that there is research proving that the marginalization of verbal aggression and its escalation may have dire consequences. Verbal aggression frequently transforms into bullying, bullying into various acts of physical aggression and in extreme circumstances the acts may lead to lynch or even genocide [51]. Thus, counteracting cyberbullying is extremely important.

Acknowledgements The authors would like to thank Jacek Banaszek, Miłosz Kościelniak-Marszał and Diana Piotrowska for providing authentic research material.

Author Contributions Aleksandra Matulewska conceptualized and designed the study, collected, selected and interpreted linguistic data, wrote the abstract, parts 2, 3, 4, 5 (co-written with Dariusz Gwiadowicz as stated below), 6, as well as edited, translated and reviewed the final manuscript. Dariusz Gwiazdowicz collected and analyzed data on reasons for hunting misperception, found illustrative material (figures 1-3), wrote part 1, and co-wrote parts 5.1 and 5.3 (collected examples 18-33 and described facts and circumstances concerning their appearance on the Internet) as well as 6.

Funding Not applicable.

Code Availability (Software Application or Custom Code) Not applicable.

\section{Compliance with Ethical Standards}

Conflict of interest Not applicable.

Availability of Data and Material (Data Transparency) The data has been obtained from public posts and victims of cyberbullying with their consent. 
Open Access This article is licensed under a Creative Commons Attribution 4.0 International License, which permits use, sharing, adaptation, distribution and reproduction in any medium or format, as long as you give appropriate credit to the original author(s) and the source, provide a link to the Creative Commons licence, and indicate if changes were made. The images or other third party material in this article are included in the article's Creative Commons licence, unless indicated otherwise in a credit line to the material. If material is not included in the article's Creative Commons licence and your intended use is not permitted by statutory regulation or exceeds the permitted use, you will need to obtain permission directly from the copyright holder. To view a copy of this licence, visit http://creativecommons.org/licen ses/by/4.0/.

\section{References}

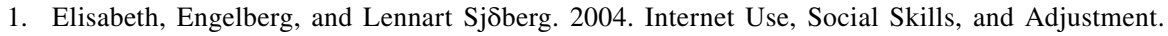
Cyber Psychology \& Behavior 7 (1): 41-47.

2. Lorenz, Konrad. 1971. Studies in Animal and Human Behavior. Cambridge: Harvard University Press.

3. Schneider, Avie. 10 January 2013. Agreed, Baby Pandas Are Cute. But Why? National Public Radio. https://www.npr.org/sections/thetwo-way/2013/01/10/169057467/agreed-baby-panda s-are-cute-but-why?t=1588755357352. Accessed 17 January 2019.

4. Borgi, Marta, Cogliati-Dezza Irene, Brelsford Victoria, Meints Kerstin, and Cirulli Francesca. 2014. Baby Schema in Human and Animal Faces Induces Cuteness Perception and Gaze Allocation in Children. Frontiers in Psychology 5 (411): 1-12. https://doi.org/10.3389/fpsyg .2014.00411.

5. Sherman, Gary D., Jonathan Haidt, and James A. Coan. 2009. Viewing Cute Images Increases Behavioral Carefulness. Emotion 9 (2): 283-285.

6. Etcoff, Nancy. 1999. Survival of the Prettiest: The Science of Beauty. New York: Anchor Books.

7. Konieczny, Andrzej. 2018. Report on the State and Condition of Forests of 2017 (Raport o stanie lasów w Polsce 2017). Warszawa: Państwowe Gospodarstwo Leśne Lasy Państwowe. https://www.bdl.lasy.gov.pl/portal/Media/Default/Publikacje/raport_o_stanie_lasow_2017.pdf. Accessed 25 March 2019.

8. Donegan, Richard. 2012. Bullying and Cyberbullying: History, Statistics, Law, Prevention and Analysis. The Elon Journal of Undergraduate Research in Communications 3 (1): 33-42.

9. Le Bon, Gustaw. 2006. Psychologia ttumu. Logos: Warszawa.

10. Chisholm, June F. 2014. Review of the Status of Cyberbullying and Cyberbullying Prevention. Journal of Information Systems Education 25 (1): 77-87.

11. Cyber Bullying Law and Legal Definition. https://definitions.uslegal.com/c/cyber-bullying/. Accessed 5 April 2019.

12. An Explanation of the Growing Phenomenon of Cyberbullying. https://www.ncpc.org/resources/ cyberbullying/what-is-cyberbullying/. Accessed February 20, 2018.

13. Patchin, Justin W., and Sameer Hinduja. 2006. Bullies Move Beyond the Schoolyard: A Preliminary Look at Cyberbullying. Youth Violence and Juvenile Justice 4 (2): 148-169.

14. Ybarra, Michele L., and Kimberly J. Mitchell. 2004. Online Aggressors/Targets, Aggressors, and Targets: A Comparison of Associated Youth Characteristics. Journal of Child Psychology and Psychiatry and Allied Disciplines 45: 1308-1316. https://doi.org/10.1016/j.chb.2011.09.004.

15. Law, Danielle M., Jennifer D. Shapka, Shelley Hymel, Brent F. Olson, and Terry Waterhouse. 2012. The Changing Face of Bullying: An Empirical Comparison Between Traditional and Internet Bullying and Victimization. Computers in Human Behavior 2: 226-232. https://doi. org/10.1016/j.chb.2011.09.004.

16. Patchin, Justin W., and Sameer Hinduja. 2006. Bullies Move Beyond the Schoolyard: A Preliminary Look at Cyberbullying. Youth Violence and Juvenile Justice 4: 148-169.

17. Bo, Xu, Xu Zhengchuan, and Dahui Li. 2016. Internet Aggression in Online Communities: A Contemporary Deterrence Perspective. Info Systems Journal 26: 641-667.

18. Brendan, Kennedy, Drew Kogon, Kris Coombs, Joe Hoover, Christina Park, Gwenyth PortilloWightman, Aida Mostafazadeh, Mohammad Atari, and Morteza Dehghani. 2018. A Typology 
and Coding Manual for the Study of Hate-Based Rhetoric University of Southern California. (preprint) The Gab Hate Corpus: A Collection of 27 k Posts Annotated for Hate Speech.

19. Bartmiński, Jerzy. Podstawy lingwistycznych badań nad stereotypem — na przykładzie stereotypu matki". In Jezzyk a kultura. T. 12: Stereotyp jako przedmiot lingwistyki. Teoria, metodologia, analizy empiryczne, eds. Janusz Anusiewicz and Jerzy Bartmiński, 63-83. Wrocław: Towarzystwo Przyjaciół Polonistyki Wrocławskiej.

20. Chlebda, Wojciech. 1998. Stereotyp jako jedność języka, myślenia i działania. In Język a kultura. T. 12: Stereotyp jako przedmiot lingwistyki. Teoria, metodologia, analizy empiryczne, ed. Janusz Anusiewicz and Jerzy Bartmiński, 31-41. Wrocław: Towarzystwo Przyjaciół Polonistyki Wrocławskiej.

21. Nikitina, Serafina F. 1998. Stereotypy jako bariery kulturowe. In Język a kultura. T. 12: Stereotyp jako przedmiot lingwistyki. Teoria, metodologia, analizy empiryczne, ed. Janusz Anusiewicz and Jerzy Bartmiński, 155-159. Wrocław: Towarzystwo Przyjaciół Polonistyki Wrocławskiej.

22. Hinduja, Sameer, and Justin W. Patchin. 2008. Cyberbullying: An Exploratory Analysis of Factors Related to Offending and Victimization. Deviant Behavior 29 (2): 129-156. https://doi. org/10.1080/01639620701457816.

23. Battistella, Edwin L. 2005. Bad Language. Are Some Words Better Than Others?. Oxford: Oxford University Press.

24. Allan, Keith, and Kate Burridge. 2006. Forbidden Words. Taboo and the Censoring of Language. New York: Cambridge University Press.

25. McEnery, Tony. 2006. Swearing in English. Bad Language, Purity and Power from 1586 to the Present. New York: Routledge.

26. Rozporządzenie Krajowej Rady Radiofonii i Telewizji z dnia 23 czerwca 2005 w sprawie kwalifikowania audycji lub innych przekazów mogących mieć negatywny wpływ na prawidłowy fizyczny, psychiczny lub moralny rozwój małoletnich oraz audycji lub innych przekazów przeznaczonych dla danej kategorii wiekowej małoletnich, stosowania wzorów symboli graficznych i formuł zapowiedzi. http://www.krrit.gov.pl/bip/Portals/0/prawo/rozporzadzenia/roz050623_ochr.pdf. Accessed 20 February 2018.

27. Gagliardone, Iginio, Danit Gal, Thiago Alves, and Gabriela Martinez. (2015). Countering Online Hate Speech. Paris: Unesco Publishing. https://unesdoc.unesco.org/ark:/48223/pf0000233231. Accessed 22 January 2019.

28. Gwiazdowicz Dariusz J. 2018. 1.1. Prehistoria. 1.2. Starożytność. 1.3. Za panowania królów w Polsce. In Kultura towiecka, ed. Dariusz J. Gwiazdowicz, 10-37. Jóżefów: Wydawnictwo Forest.

29. Gwiazdowicz, Dariusz J. 2020. Przedmowa, czyli historia łowiectwa kołem się toczy. In Łowy $i$ historia, ed. Dariusz J. Gwiazdowicz. Warszawa: Wydawnictwo Łowiec Polski, Warszawa. (in print).

30. Ustawa z dnia 13 października 1995 r. Prawo łowieckie. Dz.U. 1995 nr 147 poz. 713, tekst jednolity (The Act of 13 October 1995 Hunting Law, Polish Official Journal of Laws of 1995, no. 147, item 713 as amended, uniform text). http://prawo.sejm.gov.pl/isap.nsf/DocDetails.xsp?id=WDU1995147 0713. Accessed 25 February 2020.

31. Bartmiński, Jerzy, and Wojciech Chlebda. 2003. Problem konceptu bazowego i jego profilowaniana przykładzie polskiego stereotypu Europy. Etnolingwistyka 25: 69-95. https://doi.org/10.17951/ et.2013.25.69.

32. The Birds' Directive [Directive 2009/147/EC of the European Parliament and of the Council of 30 November 2009 on the conservation of wild birds]. https://eur-lex.europa.eu/legal-content/EN/ TXT/?uri=CELEX\%3A32009L0147. Accessed 20 September 2018.

33. The European Charter on Hunting and Biodiversity. http://www2.nina.no/lcie_new/pdf/6349915047 14143702_Hunting_Charter\%5B1\%5D.pdf. Accessed 20 September 2018.

34. Natura. 2000. Networking Program. http://www.natura.org/about.html. Accessed 14 September 2018.

35. Recommendation No. 128 (2007) of the Standing Committee on the European Charter on Hunting and Biodiversity. https://rm.coe.int/168074652a. Accessed 14 September 2018.

36. Grochowski, Maciej. 2008. Stownik polskich przekleństw i wulgaryzmów. Warszawa: Wydawnictwo Naukowe PWN.

37. Markowski, Andrzej. 2005. Kultura języka polskiego. Teoria. Zagadnienia leksykalne. Warszawa: Wydawnictwo Naukowe PWN.

38. Płóciennik, Iwona, and Daniela Podlawska. 2001. Słownik wiedzy o języku. Bielsko-Biała: Wydawnictwo Park Sp. z.o.o. 
39. Halina, Zgółka, and Zgółka Tadeusz. 2001. Mówię, więc jestem. Podręcznik języka polskiego dla licealistów. Kraków: Wydawnictwo Od Nowa.

40. Kowalikowa, Jadwiga. 1994. Znaczenie i funkcja wyrazów tzw. brzydkich we współczesnej polszczyżnie mówionej. In Wspótczesna polszczyzna mówiona $w$ odmianie opracowanej (oficjalnej), ed. Zofia Kurzowa and Władysław Śliwiński, 107-113. Kraków: Universitas.

41. Mikołajczyk, Beata. 2008. Wyrażenia znieważające jako leksykalne środki realizacji aktów zagrażających twarzy na przykładzie języka niemieckiego i polskiego. Studia Germanica Gedanensia 17: 186-197.

42. Kowalikowa, Jadwiga. 2000. Wulgaryzmy we współczesnej polszczyźnie. In Język a komunikacja 1. Zbiór referatów z konferencji Język trzeciego tysiqclecia, ed. Grzegorz Szpila, 121-132. Kraków: Tertium.

43. Siemaszko, Andrzej. 1993. Granice tolerancji. O teoriach zachowań dewiacyjnych. Warszawa: PWN.

44. Sutherland, Edwin Hardin. 1947. Principles of Criminology, 4th ed. Chicago: J. B. Lippincott Co.

45. Niech Żyją! Kampania o Żywe Ptaki. https://niechzyja.pl/kampania/co-chcemy-osiagnac/. Accessed 5 April 2020.

46. Borowicz, Adam. 2020. Społeczna ocena aktywności myśliwych. In Łowy i historia, ed. Dariusz J. Gwiazdowicz. Warszawa: Wydawnictwo Łowiec Polski, Warszawa (in print).

47. Yates, Roger. 2011. Criminalizing Protests About Animal Abuse. Recent Irish Experience in Global Context. Crime, Law and Social Change 55: 469-482. https://doi.org/10.1007/s10611-011-9298-1.

48. Bombiarz polował na myśliwych. Szaleniec miał w domu arsenał. https://www.fakt.pl/wydarzenia/ polska/warszawa/bombiarz-polowal-na-mysliwych/9trxym5. Accessed 5 April 2020.

49. W ambonie powiesili niewybuch pocisku. Atak na myśliwych w Jeziornie? https://pomorska.pl/wambonie-powiesili-niewybuch-pocisku-atak-na-mysliwych-w-jeziornie/ar/c1-14682551. Accessed 5 April 2020.

50. Ecological Business Report. 2020. [Raport "Biznes ekologiczny"] 2020. Fundacja Polska Ziemia.

51. Minton, Stephen James. 2016. Marginalisation and Aggression from Bullying to Genocide. Critical Educational and Psychological Perspectives. Berlin: Springer.

Publisher's Note Springer Nature remains neutral with regard to jurisdictional claims in published maps and institutional affiliations.

\section{Affiliations}

\section{Aleksandra Matulewska' ${ }^{1}\left[\right.$. Dariusz J. Gwiazdowicz ${ }^{2}$ (1)}

Dariusz J. Gwiazdowicz

dariusz.gwiazdowicz@up.poznan.pl

1 Collegium Novum, Faculty of Modern Languages and Literatures, Adam Mickiewicz

University, al. Niepodległości 4, Block A Room 107, 61-874 Poznan, Poland

2 Department of Forest Protection, Collegium Maximum, Faculty of Forestry, Poznań University of Life Sciences, Wojska Polskiego 28, 60-637 Poznan, Poland 